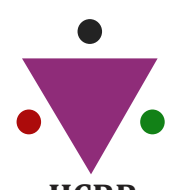

IJCRR

Section: Healthcare

Sci. Journal Impact

Factor: 6.1 (2018)

ICV: 90.90 (2018)

cc) (i) (8)

Copyright@IJCRR

\title{
COVID-19 and Indian Commerce: An Analysis of Fast Moving Consumer Goods (FMCG), and Retail Industries of Tomorrow
}

\author{
Gaurav Shetty ${ }^{1}$, Shrey Nougarahiya ${ }^{2}$, Dheeraj Mandloi ${ }^{3}$, Tapesh Sarsodia ${ }^{4}$, \\ Sapna Jain Dabade ${ }^{5}$
}

'Department of Professional Studies, Christ (Deemed to be University), Bengaluru, India; ${ }^{2}$ Institute of Engineering and Technology, Devi Ahilya University, Indore, India; ${ }^{3}$ Department of Applied Science, Institute of Engineering and Technology, Devi Ahilya University, Indore, India; ${ }^{4}$ Department of Electronics, Institute of Engineering and Technology, Devi Ahilya University, Indore, India; Department of Applied Science, SAGE University, Indore and Research Scholar at School of Chemical Sciences, Devi Ahilya University, Indore, India

\section{ABSTRACT}

Introduction: This paper examines the effect of COVID-19 on Fast Moving Consumer Goods (FMCG) and Retail industries of India and examines emerging trends in these markets.

Background: COVID-19 has impacted our lives from all the fronts. Businesses and Global Commerce will never be the same once the world restarts post COVID-19. Multiple new trends like Direct to Consumer model(D2C), Omnichannel fulfilment, etc. would emerge in the industries of tomorrow. Macroeconomic Dynamics, consumer behaviour and supply-side disruptions form a complex network that drives these trends in the economy. This network has to be studied to proactively identify the emerging trends in the industry.

Methods: Existing literature on COVID-19 and its effect on business and commerce in India were retrieved through secondary research. The retrieved literature was analyzed to identify emerging trends.

Conclusion: Emerging trends in FMCG and Retail industry suggest that the previously existing layers of wholesalers, distributors, etc. between the producer and the end consumer is being eliminated. Companies are leveraging technology to achieve direct distribution and thus, are getting closer to the customer.

Key Words: COVID-19, Fast-moving consumer goods (FMCG), Retail, Post COVID FMCG, COVID-19 and Commerce, COVID -19 and Business

\section{INTRODUCTION}

2020 will be remembered in history, as Coronavirus disease 2019 (COVID-19) has come up as an event that will remain imprinted in us for a long time. COVID-19 is an infectious disease caused by Severe Acute Respiratory Syndrome Coronavirus 2 (SARS-CoV-2), a novel virus. ${ }^{1}$ It was first identified in December 2019, in Wuhan, the capital of China's Hubei province and has since then spread globally across $213+$ countries. $^{2}$ The virus has taken the whole world in its grip and the coronavirus outbreak has been coined as a pandemic by WHO. ${ }^{3}$ With 677,017 deaths and over 17.4 million people affected (as of July 31, 2020), this disease has put the entire world under lockdown.

'The Great Shutdown' due to COVID-19 is speculated to lead us to a global recession, which is feared to be more devastating than 'The Great Depression' of 1930. ${ }^{4}$ This has stirred an uncertain situation which would have severe economic repercussions for economies across the world, with unemployment at peak and significant stagnation of consumerism. The recession is speculated to cause the collapse of the price of oil, the collapse of the tourism industry, hospitality industry, energy industry and a significant downturn in consumerism in comparison to the previous decade. Global stock markets crashed around $20 \%$ to $30 \%$ during late February and March 2020 accompanied by unprecedented and volatile swings due to extreme uncertainty. ${ }^{5}$

India, the second-most populous country in the world is under high risk. The first case of COVID-19 pandemic in India was reported in January. The country went into complete lockdown from $23^{\text {rd }}$ March onwards, with most of the indus-

\section{Corresponding Author:}

Dheeraj Mandloi, Institute of Engineering and Technology, Devi Ahilya University, Indore, MP, India

Phone: +91 9407894470; Email: dmandloi@ietdavv.edu.in

ISSN: 2231-2196 (Print)

Received: 09.07.2020
ISSN: $0975-5241$ (Online)

Revised: 06.08 .2020
Accepted: 29.08 .2020
Published: 08.09 .2020 
tries and businesses under complete shutdown till date. The Ministry of Health and Family Welfare has confirmed a total of 1,643,416 cases, 1,059,983 recoveries, 35,807 deaths in

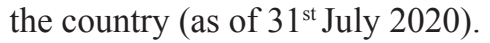

The shutdown will have significant effects on informal workers, self-employed and those engaged with MSMEs. In the retail segment, shopping centres and other retailers across the country have reduced hours or closed down entirely, departmental stores and clothing shops have been especially hit. Many of these retailers are expected not to recover, thereby accelerating the effects of the retail apocalypse. Tourism, Automobile, Aviation, Real estate, Dining, and Luxury goods industries are almost non-functional. Unlike other recessions in the past, this pandemic has brought down the sales of some sectors to zero. Due to restrictions on transportation and manufacturing halts, the supply chains are disrupted creating demand-supply imbalances. Also, disrupted food supplies threaten to trigger a food crisis. ${ }^{6}$

In this paper, we first examine the macroeconomic impact of COVID-19 on the Indian economy. We then move on to analyse the demand and supply disruptions due to COVID-19 in two major sectors of our economy - Retail, and Fast Moving Consumer Goods (FMCG). Using this analysis, the study portrays the markets of tomorrow the challenges and possible strategies for the businesses to face them.

\section{Macroeconomics of COVID-19: Economic Impact on India}

COVID-19 arrived in India at a time when we were already battling the slowing consumption in our domestic market.2019 saw events like the US-China trade war and Brexit. Economic vulnerability already had a dark shadow on our global economy and its impact on our GDP was evident. ${ }^{7}$ COVID-19 came in the wrong time and added supply-side disruptions as well along with the slowing domestic and global consumption/demand. Disruptions in supply and weak demand causes a series of spiral macroeconomic problems for any economy. ${ }^{8}$ While multiple sectors lost their demand or started seeing zero demand, sectors like FMCG and Pharmaceuticals saw increased demand, but could not fulfil them due to the supply-side disruptions in sourcing raw materials and logistics/distribution challenges. The recovery scenarios are difficult to predict considering that Indians are conservative spenders and thus a possible further drop in demand. This sentiment is evident with analysts drastically reducing the 2020 outlook for Gross domestic product(GDP) growth of the Indian economy, as observed in Figure 1.

India had a slow GDP growth in the year 2019, with a growth rate around 5\% in all the quarters of $2019 .{ }^{9}$ Weak financial institutions, underlying structural weaknesses due to policy matters resulted in low investor confidence on the supply side of the economy and issues like unemployment impacted the demand side of the economy. While 2019 was the slow year, 2020 was looked upon as a year that will bring back India's GDP into the growth track and most of the outlooks for the FY21 GDP growth rate were optimistic between 5.2\% $-6.6 \%$.

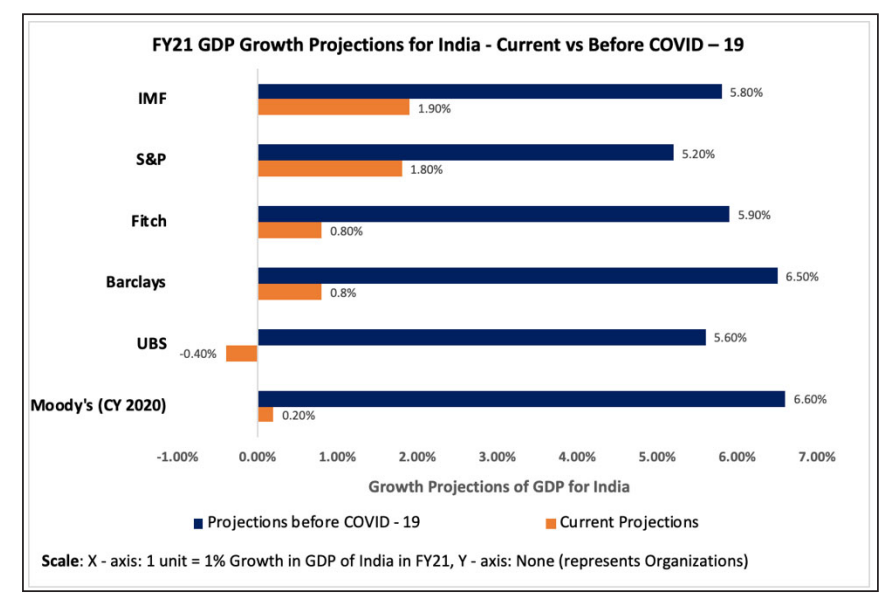

Figure 1: FY21 GDP Growth Projections for India - Current vs Before COVID-19. Data from IMF, S\&P, Fitch, Barclays, UBS, Moody's (2020).

However, COVID-19 changed these outlooks. Historically, a recession has always been due to a liquidity crunch caused by weak financial institutions. Several economic measures and tools are available with the Governments to face these challenges. However, probably it is the first time in the history of Global markets; we are facing a recession due to people not being able to get to work. Most economic indicators suggest that some of the biggest economies are on the verge of the greatest real recession in nearly 100 years. ${ }^{10}$ The trauma of financial markets coupled with the sudden stop of all economic activities and the reduced domestic/global demand will lead to many serious problems like high unemployment and left unchecked, we might be staring at stagflation or depression, something more serious than recession. ${ }^{11}$

Along with the domestic impact of reduced consumption, factory shutdowns and travel restrictions, India would also be affected by the external impact due to COVID-19 - Weaker global demand (fewer exports), supply chain disruptions, and global financial shocks. ${ }^{12}$ The analysis of the export and import share of India to/with the world's most severely affected countries (that has $67 \%$ of the COVID-19 confirmed cases) shows that highly affected 10 countries accounted for $43 \%$ of India's exports and 39\% of India's imports in 2018 - 19 as shown in Figure 2. ${ }^{13}$ Our calculations also show that these countries account for $59 \%$ of the world GDP that indicates a global financial slowdown. In 2020, the export to 
these countries from India will decrease due to reduced demand and this would severe the impact of COVID-19 on the Indian economy as a whole as the foreign reserves of India would fall.

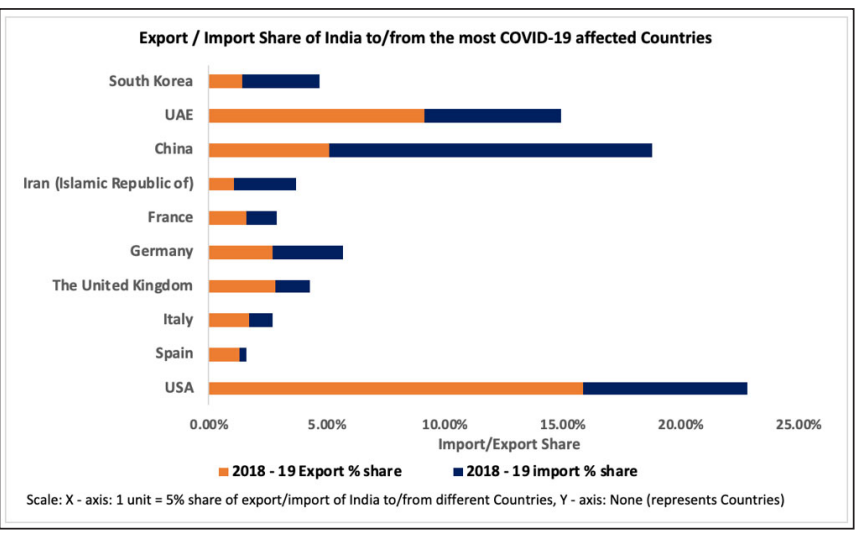

Figure 2: Export / Import Share of India to/from the most affected countries by percentage in 2018 - 19. Data from the Ministry of Commerce and Industry, Government of India ${ }^{14}$

\section{Sector-wide Impact}

While it is evident from the previous analysis that we are staring at a negative to zero growth in GDP, the impact of COVID-19 on sectors has not been uniform, unlike a financial recession. During a crisis like COVID-19, industries can be classified into three buckets based on Market demand and recovery probabilities,

a) Stable or Increasing Demand: Currently, these industries are not able to cope up with the demand and will continue to have high demand post-COVID 19 impact. These sectors will not see recessionary trends Examples: Essential sectors like FMCG, E-grocers and delivery centres.

b) Suspended Demand: These industries currently have low to zero demand but will spike and recover the suspended demand post-COVID 19 impact. Recession trends would depend upon government fiscal policies and cash flows. Examples: Discretionary sectors like Automotive, Apparel, Consumer durables, etc.

c) Lost Demand: These industries currently have low to zero demand. The demand lost will be permanent and cannot be recovered post-COVID 19 impacts. Demand will not fully resume to normalcy postCOVID 19 leading to recessionary trends. Examples: Service sectors - Travel and tourism, Malls and theatres etc.

Since demand and recovery scenarios vary for different sectors, the impact and strategies for recovery also differ from sector to sector. Figure 3 indicates the varying negative impact on different sectors of the Indian market due to COVID -19 .

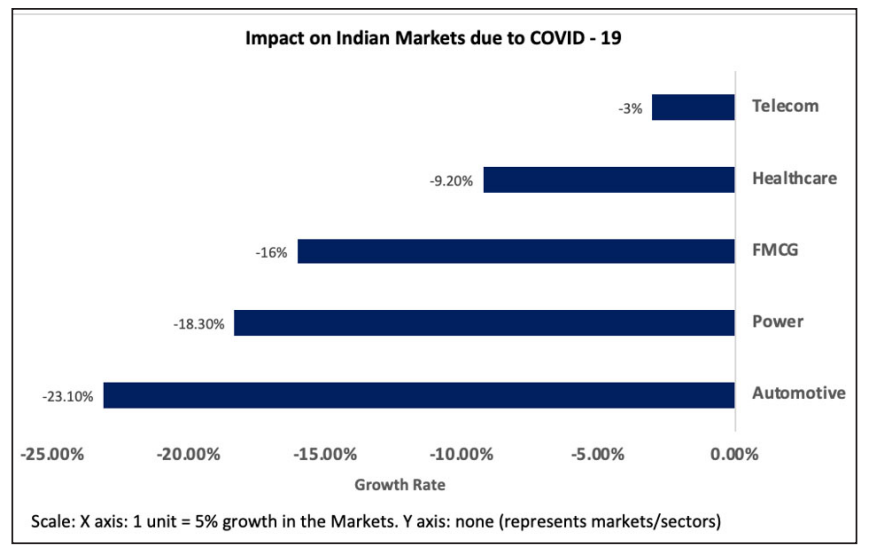

Figure 3: Impact on Indian Markets due to COVID-19. Data from Bloomberg (2020), Mint (2020) ${ }^{15}$

Demand and Supply Analysis - FMCG

Fast-moving consumer goods are the fourth largest sector in the Indian economy. ${ }^{16}$ The growth of this market has been mostly in double-digit, closely linked with the GDP growth of the Indian economy. Better macroeconomic indicators would mean consumers would have better spending power and that essentially translates into a better growth for the FMCG sector. Also, most of the essential goods fall into this sector, which is another reason for high growth.

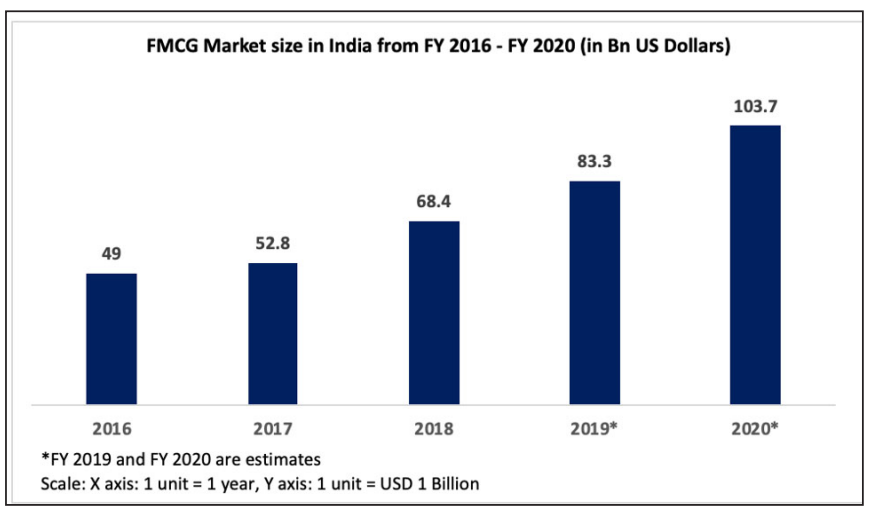

Figure 4: FMCG Market size in India from FY 2016 - FY 2020 (in Bn US Dollars).

Data from Statista ${ }^{17}$

It can be seen from figure 4 that FMCG has seen consistent growth from 2016 till date and the future of this sector has been pledged very prospective as well. However, CY 2019 has not been very promising for the FMCG sector. According to the market research firm Nielson, the growth slowed down to $9.7 \%$ from $13.5 \%$ in the year 2018 . The growth slowed down to $6.6 \%$ in the December quarter, the lowest in the last three years. This growth is also much lower to $15.7 \%$, the growth rate a year ago. ${ }^{18}$

Rural sales have always been ahead of urban sales in the FMCG Industry. ${ }^{19}$ Rural sales of FMCG saw slow growth in 2019. This can be attributed to reduced GDP growth rate, 
liquidity crunch in the markets which weakened the household consumption. Along with liquidity pressure, consumer spending was also weak due to low job addition, no salary hike, etc. Adding to all these were the floods and drought in the rural part, that indirectly resulted in high food inflation, that impacted the consumer. ${ }^{20}$

The FMCG Sector was expected to be back on track in 2020. Nielson had predicted a growth rate of $9-10 \%$ for the FMCG market in the CY 2020 before COVID-19. GDP was expected to be back on the track, Monsoon was expected to be good, Government spending on infra projects was expected to increase, and all these gave indications of money in the hands of consumers and thus a bright year for the FMCG sector.

However, with COVID-19 coming into the picture, Nielson has slashed the growth rate of the FMCG sector to $5-6 \%$ from its earlier $9-10 \%{ }^{21}$ In the quarter ending March, FMCG sector grew 6.3\% (including e-commerce) in value turns, which is a sharp downward trend compared to the $13.8 \%$ growth the sector saw in the same period in $\mathrm{CY}$ $2019 .{ }^{21} \mathrm{An}$ interesting break up from this data point is that demand for packaged food segment of FMCG grew by $7.8 \%$ in March quarter of 2020, compared to non - food categories which grew only $1.8 \%$ in value. This trend points out at the panic buying and stockpiling of the food items that occurred in the Indian market at the end of March quarter as the country prepared for the lockdown.

Despite the panic buying and stockpiling trend that occurred at the end of March quarter in the FMCG sector, 2020 looks like a gloomy year for the sector. It is evident that while the stockpiling trend would increase sales once, then the demand would stabilize as the consumers would have enough stock. Also, since COVID-19 has hit the economy the most, money would not flow to consumers and thus consumers would resort to conservative spending, which essentially translates into a hit on the FMCG sector.

Immediate Impact of COVID-19 on Demand and Supply in FMCG Industry of India can be summarized in the below points

1. Panic buying increased the demand in the industry initially. However, the demand would stabilize soon.

2. Essential products like packaged food, groceries, health and hygiene products like soap, sanitizers, etc. saw unprecedented demand.

3. FMCG companies struggled to serve the market demand at the panic buying phase in the last weeks of March and the first half of April, due to disruptions in their supply chain - from sourcing raw materials, manufacturing, till last-mile distribution. With lockdown and travel restrictions, companies are still producing at sub-optimum levels and pushing sales of only essential items.
4. The disruptions in manufacturing and distribution due to lockdown resulted in the drying up of inventory amongst the retailers, which impacted the supply of products to the consumers.

\section{Demand and Supply Analysis - Retail}

Retail is one of the largest segments in the Indian economy, that contributes to $40 \%$ of India's consumption and employs an approximate of $40-50$ million people. ${ }^{22}$ With consumption of $\$ 1.7-1.8$ trillion and an estimated CAGR of $9-11 \%$ from $2019-2025$, the retail segment is a breadwinner for many families. While there is a clear picture of organized retail segment/modern trade, data points are not available for the magnificent traditional trade segment, and it is estimated that a large number of Indians are dependent on the Retail segment for their livelihood.

COVID-19 has had a significant impact on retail on multiple fronts. In India, with mandatory lockdown, all retail shops and the entire modern trade was asked to shut down for more than 2 months, except establishments that sold essential goods. However, according to an estimate from the RetailAssociation of India (RAI), only $8 \%$ of the retail segment in India sold essential goods. ${ }^{23}$ This implies that $92 \%$ of the establishments saw zero sales for close to two months.

While the data is not out yet for the lockdown period in the Indian retail segment, we can look at data from China during their lockdown period. China imposed lockdown and drastic travel restrictions to contain COVID-19 in January, February, and March and the figure 5 indicates the drop of retail sales of consumer goods to $-20.5 \%$ in January and February. The drop can also be seen during May - 2003 in China, when SARS - 2003 was at its peak and there were similar restrictions on movement. A similar drop in retail sales of consumer goods can be expected in India for the months of Q1 2020 and Q2 2020, considering that most of the establishments were ordered to be closed.

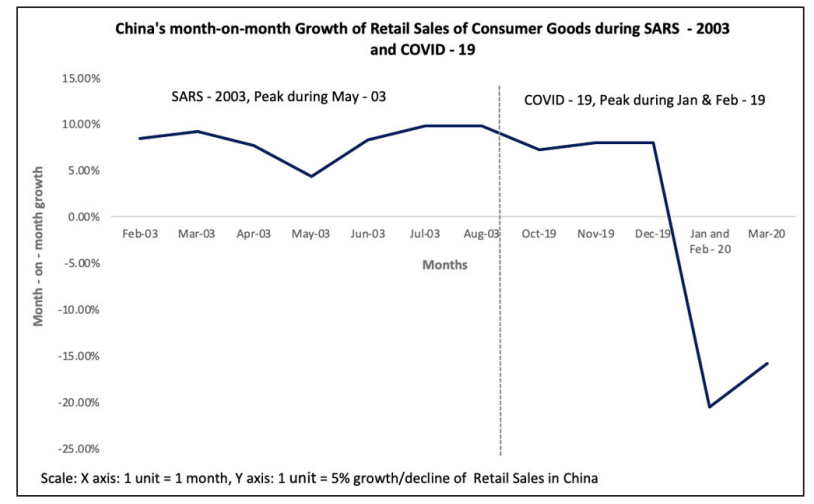

Figure 5: China's month-on-month Growth of Retail Sales of Consumer Goods during SARS - 2003 and COVID-19.

Data for February - 2003 till August - 2003 from the National Bureau of Statistics of China Through CEIC (2004), Data from October - 2019 till March - 2020 from Statista ${ }^{24}$ 
Below are the likely disruptions in the Indian retail segment due to the drop of Sales and changing consumer behaviour; ${ }^{25}$

1. Ballooning of Inventory: Unlike FMCG, where there was a trend of drying up of inventory of essential goods, in non-essential goods retail segment, there is a likely ballooning of inventory in stores and warehouses since summer inventory is still lying in the stores and next season inventory(autumn or festive) are lying in the warehouse due to advanced orders (longer lead time for orders).

2. Higher discounting to excess inventory: Retailers would be forced to run multiple discounting schemes to attract conservative customers so that they can generate some liquidity and also liquidate lying inventory. This would dilute the margins and would hit the profitability of the entire segment. Inventory from the past season that might not move may have to be written off.

3. Cash crunch or liquidity issues: Ballooning of inventory would lead to low liquidity and cash crunch for almost all retailers. Also, smaller retailers without enough buffers might be forced to shut down the business.

4. BOPIS (Buy Online and Pick up in the store) is being encouraged and is being practised by many modern retailers due to delivery challenges

5. Multi-brand retailers are becoming Omnichannel - deliver by themselves, or collaborate with other last-mile partners. For example, Future Group, which serviced online orders for groceries only from its Easy Day stores in Delhi NCR, has extended that capability to 250 of its Big Bazaar stores across the country. Kolkata-based Spencer's Retail has also partnered with internet firms like food delivery platform Swiggy, cab-hailing app Uber and bike taxi start-up Rapido to deliver orders placed by customers on its website

The retail sector consists of multiple segments under it like online retail, essential goods, automobile retails, etc. With varied segments, the impact of COVID-19 on all these have not been uniform and has been at various levels. An examination of China's total retail sales broken down by segments during the period of lockdown - January and February 2020 would give an understanding of the level of impact on various segments under retail. A similar drop in sales and impact can be predicted for segments under India retail as well during the period of the lockdown and subsequent quarter after it, based on the recovery scenarios, which we will examine in the latter part of this paper.

It can be observed from figure 6 below, that the non-essential segment of retail is being hit the most during the lockdown. The hypothesis of the increase in sales of food grains due to panic buying and increasing e-commerce penetration in retail (e-tail) can be confirmed from the below data points. While all other retail segments have seen a negative growth rate, online retail sales of physical goods, Grain and food- stuff, and beverages segment have seen a positive growth rate of $3 \%, 9.70 \%$ and $3.10 \%$ respectively. The most impacted retail segments have been an automobile, furniture, and Garments with the steepest negative growth rate of $-37 \%$, $-33.5 \%$, and $-30.90 \%$ respectively. Similar trends can be predicted for the Indian market as well, except for the beverages segment, which is expected to see a negative growth due to the lockdown orders.

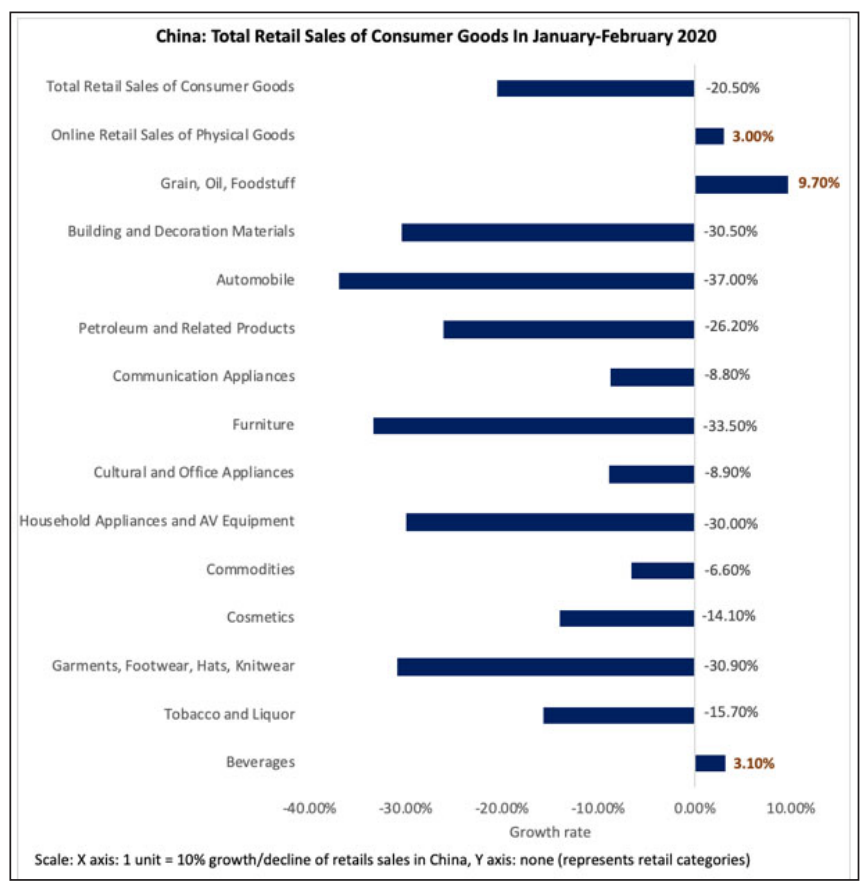

Figure 6: China: Total Retail Sales Growth Rate of Consumer Goods in January-February 2020.

Data from the National Bureau of Statistics of China ${ }^{26}$

According to a report by the retail intelligence platform $\mathrm{Bi}$ zom, Indian retailers suffered a significant $71 \%$ drop in demand during the first week of lockdown. ${ }^{27}$ Confectionary is the worst hit category, after beverages. The report reveals that the sales in this segment were down almost $25-30 \%$ after Holi and similar trends might continue till May end.

\section{Discussion: Recovery Scenarios - Markets of Tomorrow}

COVID-19 would impact commerce in three major streams - reduced labour supply, reduced demand and supply in specific industries, and rising trade costs. ${ }^{28}$ In terms of recovery scenarios, three scenarios were proposed by WTO. The VShaped scenario is assumed to be the optimistic scenario, in which health-related effects and the social distancing measures are expected to go away quickly. In a U - shaped scenario, which is considered as mildly pessimistic, the social distancing measures are expected to stay for around 6 months. In an $\mathrm{L}$ - shaped scenario which is a pessimistic scenario, the social distancing measures are expected to stay for around a 
year. The demand and supply recovery of different sectors in the commerce post - COVID are expected to differ based on what recovery scenario, the respective economy and global economy goes through and the impact is expected to vary between sectors within an economy as well. The below table illustrates the change in the GDP growth rate of different countries in these scenarios of recovery.

Table 1: Per cent Deviation of GDP from Baseline
\begin{tabular}{lccccccc} 
Real GDP & V - shaped & U - Shaped & L - Shaped \\
& 2020 & 2021 & 2020 & 2021 & 2020 & 2021 \\
\hline ASEAN & -6.1 & 4.6 & -12.2 & 9.7 & -14.7 & 3.3 \\
China & -4 & -3.5 & -7.9 & 7.2 & -9.9 & 2.5 \\
European Union & -5.2 & 4.1 & -10.1 & 8.4 & -12.1 & 2.9 \\
India & -5.4 & 4.6 & -11.1 & 9.9 & -13.4 & 3.2 \\
United States & -5 & 4.8 & -8.8 & 8.6 & -10.8 & 2.9 \\
Japan & -4.4 & 3.9 & -8.1 & 7.4 & -9.5 & 2.4 \\
Other Asian & -5.8 & 5.1 & -11.4 & 10.3 & -13.4 & 3.2 \\
Countries & & & & & & \\
\hline
\end{tabular}

Data from WTO (April 2020) ${ }^{28}$

Concerning the Indian economy, the initial impact of COVID-19 was the supply chain disruptions due to the non-availability of raw materials from China. It was expected that the recovery would be V-Shaped, given that COVID-19 was limited to China. However, with COVID-19 being declared as a pandemic, the V-Shaped recovery is expected to be unlikely and a $U$ - shaped recovery is expected. But if the spread of COVID-19 continues at the current rate and spreads in the community, then the recovery might be a long path and India might see an L - shaped scenario with severe impact on its economy. With an $\mathrm{L}$ - shaped scenario, the economy is expected to be stuck in recession throughout the year and the economy might take a long time to come back to normalcy. ${ }^{29}$ In case of a $\mathrm{U}$ - shaped scenario, it is expected that the supply chain problem/sluggish global demand would intensify and the Indian economy bounces back to normalcy in Q4 FY 2021. On the other hand, in case of an $\mathrm{L}$ - shaped scenario, the situation would ease in Q1 FY 2022. ${ }^{30}$

\section{FMCG Recovery Scenario and Market of Tomor- row}

While the overall outlook for the FMCG has been good compared to all other sectors in the economy, given that most of the segment falls under the segment of essential goods, the recovery scenario is expected to be V-Shaped or U - shaped depending on the category of goods.

FMCG weekly value growth rate data for China from Kantar Worldpanel indicates the recovery scenarios of the FMCG industry for different segments of goods. ${ }^{31}$ The results from the study are summarized below,

- Categories like personal hygiene products and home cooking products, packaged food, etc. saw a growth in China during COVID-19 lockdown and in the period of recovery after that. These categories saw growth in the said period.

- Categories like toilet papers, pet food, etc. saw a limited impact, with an increase in demand and a brief decline. The curve of decline was not steep and return to normalcy was quick. These categories did see the trend of panic buying in the beginning. However, these are not products which are consumed daily. Thus, the stockpiling would have resulted in the reduction of demand.

- Categories that include products like cooking oil, yoghurt, biscuits, nutritional supplements and laundry detergent saw a decline in consumption but were quick to recover the lost demand and return to normalcy in China. This segment of FMCG saw a $V$-shaped recovery from COVID-19.

- On the other hand, categories with products like shampoo, skincare, makeup, etc. saw a steep decline in demand during the peak of COVID-19 and are yet to recover, after 6 weeks of the lifting of lockdown. These are expected to see a $U$-shaped recovery and are expected to return to complete normalcy only by end of Q2 2020.

Similar trends are expected in India given the similarity in our consumption pattern. Different categories of products are expected to see different recovery patterns.

While we saw the demand-side recovery scenarios of the FMCG sector due to COVID-19, it is necessary that we also inspect the supply-side impact. COVID-19 has disrupted supply side in two major ways,

1. Supply chain disruption - Due to severe restriction on the movement in India, all nodes of supply chains are being impacted starting from sourcing of raw materials, until the last-mile delivery of the finished goods. The severe impact has been on the distribution sector of the supply chain

2. Manufacturing shutdown - Lockdown in the country has impacted the production of the goods and even when there are permits to continue production, most of the factories are operating at the sub-optimum levels due to labour shortages and the social distancing guidelines

While the second point has been a temporary disruption, the first disruption of the supply chain give rise to many interesting trends that might shape up the FMCG sector of tomorrow. We will examine one such trend in this paper.

Traditionally, FMCG Supply chain has had several layers between the manufacturer and the retailer, who would distribute the products to the consumers. With COVID-19, this 
network was disrupted and the companies struggled to move goods from one level to another. This resulted in two phenomena in the market - Direct to Consumer Model (D2C) and partnerships with ride-hailing services for delivery. Both of these phenomena are interrelated.

Though D2C has not been a new model, many companies which followed traditional supply chain models had no plans of adopting the D2C model. In D2C, the FMCG companies would try to eliminate all the intermediate levels between itself and the consumer. These levels would have distributors, wholesalers, etc. The company would try to directly reach the retailer or the consumer. This model has its inherent advantages and disadvantages.

COVID-19 has accelerated this phenomenon and FMCG companies are directly trying to reach the consumer eliminating all the intermediate levels. Companies are partnering with ride-hailing services like Dunzo, Rapido, etc. for efficient distribution. Some examples are highlighted in Table 2

\section{Table 2: Partnerships of FMCG Companies with Last mile/Distribution providers in India}

\begin{tabular}{|c|c|c|}
\hline Company & $\begin{array}{l}\text { Last-mile/Distri- } \\
\text { bution Partners }\end{array}$ & $\begin{array}{l}\text { Cities where the partner- } \\
\text { ship is operational }\end{array}$ \\
\hline Marico $^{32}$ & Zomato, Swiggy & $\begin{array}{l}\text { Mumbai, Gurugram, Kolkata, } \\
\text { Chandigarh, Ahmedabad }\end{array}$ \\
\hline ITC $^{33}$ & $\begin{array}{l}\text { Domino's (Jubilant } \\
\text { Food Works) }\end{array}$ & $\begin{array}{l}\text { Bengaluru, Mumbai, Noida, } \\
\text { Hyderabad, Kolkata, Chennai }\end{array}$ \\
\hline Britannia $^{34}$ & Dunzo & $\begin{array}{l}\text { Metropolitan cities - Con- } \\
\text { sumers can order Britannia } \\
\text { biscuits, cakes and milk- } \\
\text { shakes by placing their orders } \\
\text { in the Britannia Essentials } \\
\text { Store on the Dunzo app }\end{array}$ \\
\hline $\begin{array}{l}\text { Spencer's } \\
\text { Retail } 35,36\end{array}$ & $\begin{array}{l}\text { Uber India, Rapido, } \\
\text { Scootsy }\end{array}$ & $\begin{array}{l}\text { Mumbai, Gurugram, Cochin, } \\
\text { Hyderabad, Haridwar, Chen- } \\
\text { nai }\end{array}$ \\
\hline
\end{tabular}

While these partnerships might be temporary, companies who tried out D2C model during COVID-19, might examine this model in the post COVID times, and there is a possibility that market of tomorrow would see multiple FMCG companies adopting D2C supply chain model and shunning the traditional supply chain model they always had. This might change the function and role that distributors and wholesalers played in the market.

\section{Retail Recovery Scenario and Market of Tomorrow}

The retail segment is broadly classified into discretionary and non - discretionary sectors. Due to the lockdown, the non-discretionary retail sector is completely shut down and the recovery seems to be bleak for this sector. According to the Retail Association of India, only $7-8 \%$ of the retail industry is functioning and the rest $92 \%$ is shut down. ${ }^{37}$

Similar to FMCG, various sectors within retail are expected to have different recovery scenarios. Categories of retail like packaged food and commodities saw the fastest recovery. Essential retail saw growth during COVID-19 lockdown in India. Categories like homecare saw an increase in demand in the last weeks of March, due to the month-end buying pattern and announcement of lockdown. This category has seen a limited impact and is expected to recover quickly. ${ }^{38}$

Beverages and Confectionery saw a complete shut down for a while during the lockdown. But the demand picked up with the relaxation of the lockdown and we expect this category to see a V-shaped recovery. However, discretionary retail categories like furniture, apparel, garments, footwear, etc. are the most impacted with zero sales for 2 months of the lockdown. These categories will see problems like ballooning of inventory and liquidity crunch, which might result in many small businesses being wiped out. We expect these categories to see a $\mathrm{U}$ - shaped recovery in terms of demand.

On the supply side, e - tailor e - grocery has received significant attention for essential goods. Most of the modern retail giants have tied up with e-commerce players for an effective fulfilment. As seen from the above table, a major example here being Future Group's Big Bazaar, which partnered with Rapido and Scootsy for distribution ${ }^{39}$. Cash and Carry retailers such as Metro have started direct distribution to their Kirana partners. ${ }^{40}$

Though e-tail has received significant attention, it is the local brick or mortar shops or the Kirana shops that emerged as a winner in this scenario. Though modern retail tied up with online platforms for distribution, procurement was a challenge for them and they could not fulfil the increasing consumer demand during the lockdown. A major trend that was observed in India during the lockdown phase is that people started buying from their neighbourhood Kirana stores. Neighbourhood stores also started home delivery in their locality. If the small neighbourhood stores get digitized and focus on customer convenience, we expect the trend of increasing modern trade penetration to reverse, and traditional retail might still hold the ground concerning India.

Omnichannel fulfilment has been a major trend in the retail industry since the second half of this decade. Almost all major retail chains were trying to reinvent their distribution model and were trying to find alternate channels to reach the customer and to attain higher customer satisfaction. With COVID-19, Omnichannel fulfilment has moved on to be a necessary factor, from being a differentiating factor as it was in the past. If a retailer, be it modern trade or traditional trade, does not think of Omnichannel fulfilment and innovative ways of reaching his customer, he would not be able to 
survive in the market of tomorrow.

\section{CONCLUSION}

COVID - 19 has disrupted our lives. The world will never be the same. While the industry is expecting a return of the normal from the pre - COVID world, it is evident for most of the companies that a new normal is emerging and that is different from what was normal in our past.

While we have examined major trends like direct to consumer model in FMCG and omnichannel fulfilment in retail, multiple trends are emerging - both due to the changing customer expectation and due to the disruptions in the supply chain. Dynamics in the economy is driving these changes. To survive in the market of tomorrow, in the post COVID world, a firm must be proactive in identifying these trends and must adapt to them. While we might see companies like Alibaba emerging from these situations, current giants are also in the risk of falling from their glory.

\section{ACKNOWLEDGEMENT}

Authors acknowledge the immense help received from the scholars whose articles are cited and included in references to this manuscript. The authors are also grateful to authors/ editors/publishers of all those articles, journals and books from where the literature for this article has been reviewed and discussed

\section{Sources of funding: None.}

\section{Conflicts of interest: Nil}

\section{REFERENCES}

1. World Health Organization. Naming the coronavirus disease (COVID-19) and the virus that causes it. Published Online. 2020. https://www.who.int/emergencies/diseases/novel-coronavirus-2019/technical-guidance/naming-the-coronavirus-disease-(COVID-2019)-and-the-virus-that-causes-it

2. World Health Organization. Pneumonia of unknown cause China. Published Online. January 5, 2020. https://www.who.int/ csr/don/05-january-2020-pneumonia-of-unkown-cause-china/ en/

3. World Health Organization. WHO Director-General's opening remarks at the media briefing on COVID-19 - 11 March 2020, Published Online. March 11, 2020. https://www.who.int/dg/ speeches/detail/who-director-general-s-opening-remarks-at-themedia-briefing-on-covid-19---11-march-2020

4. Gopinath G. The Great Lockdown: Worst Economic Downturn Since the Great Depression. IMF. Published Online. April 14, 2020. https://blogs.imf.org/2020/04/14/the-great-lockdownworst-economic-downturn-since-the-great-depression

5. BBC.Global shares plunge in worst day since the financial crisis. Published Online. March 9, 2020. https://www.bbc.com/ news/business-51796806
6. Reddy P. Fighting COVID-19 with facts, not fear: How India can get back to work after coronavirus lockdown. Business Today. Published Online. May 2020. https://www.businesstoday. in/opinion/columns/covid-19-coronavirus-lockdown-how-india-can-get-back-to-work-indian-economy-gdp/story/402041. html

7. KPMG. COVID - 19: The many shades of a crisis. Published Online. April 2020. https://assets.kpmg/content/dam/kpmg/in/ pdf/2020/04/the-many-shades-of-a-crisis-covid-19.pdf

8. Mishra A. R., Prasad G. C. Indian economy braces for coronavirus - induced shock as curbs set to pull down growth.Mint. Published Online. March 15, 2020. https://www.livemint.com/ news/india/indian-economy-braces-for-coronavirus-inducedshock-as-curbs-set-to-pull-down-growth-11584293920159.html

9. Press Trust of India. India's GDP growth rate for 2019-20 estimated at 5\% against $6.8 \%$ in FY19. Published Online. January 7, 2020, https://www.business-standard.com/article/economypolicy/gdp-first-advance-estimates-predict-economic-growthat-5-in-2019-2020-120010700990_1.html

10. KPMG. COVID - 19: The many shades of a crisis. Published Online. April 2020. https://assets.kpmg/content/dam/kpmg/in/ pdf/2020/04/the-many-shades-of-a-crisis-covid-19.pdf

11. Boissy F., Rungcharoenkitkul P. Macroeconomic effects of Covid-19: an early review. Bank for International Settlements. Published Online. April 17, 2020. https://www.bis.org/publ/bisbull07.pdf

12. CRISIL. The COVID - 19 fallout. Published Online. March 19, 2020. https://www.crisil.com/content/dam/crisil/our-analysis/ views-and-commentaries/impact-note/2020/march/the-covid19-fallout.pdf

13. World Health Organization. Coronavirus disease (COVID - 19) Situation Report - 102. Published Online. May 1, 2020. https:// www.who.int/docs/default-source/coronaviruse/situationreports/20200501-covid-19-sitrep.pdf?sfvrsn=742f4a18_2

14. Ministry of Commerce and Industry, Government of India. EXPORT-IMPORT DATA BANK Version 7.1 - TRADESTAT. Available Online. Accessed on 23 May 2020. https://commerceapp.gov.in/eidb/Default.asp

15. Mishra A. R., Prasad G. C. Indian economy braces for coronavirus - induced shock as curbs set to pull down growth.Mint. Published Online. March 15, 2020. https://www.livemint.com/ news/india/indian-economy-braces-for-coronavirus-inducedshock-as-curbs-set-to-pull-down-growth-11584293920159.html

16. Indian Brand Equity Foundation. Indian FMCG Industry Analysis. Published Online. March 2020. https://www.ibef.org/industry/Fmcg-presentation

17. Statista. India FMCG Market Size. Available Online. Accessed on 23 May 2020. https://www.statista.com/statistics/742463/ india-fmcg-market-size/

18. Malviya S., Bhushan R. FMCG likely to grow $9-10 \%$ in 2020 : Nielsen. The Economic Times. Published Online. January 22, 2020. https://economictimes.indiatimes.com/industry/consproducts/fmcg/fmcg-likely-to-grow-9-10-in-2020-nielsen/articleshow/73509399. cms?from $=$ mdr

19. PTI. The decline in rural sales hit FMCG in 2019, revival likely by the second half of 2020. The Economic Times. Published Online. December 31, 2019. https://economictimes.indiatimes. com/industry/cons-products/fmcg/decline-in-rural-sales-hitsfmcg-in-2019-revival-likely-by-second-half-of-2020/articleshow/73041851.cms?from $=$ mdr

20. Subramanian A., Felman J. India's Great Slowdown: What Happened? What's the Way Out?. Harvard University. Published Online. December 2019. https://www.hks.harvard.edu/sites/ default/files/centers/cid/files/publications/faculty-working- 
papers/2019-12-cid-wp-369-indian-growth-diagnosis-remediesfinal.pdf

21. Tandon S. Nielsen projects a gloomy year for FMCG companies. Mint. Published Online. April 20, 2020. https://www.livemint.com/news/india/nielsen-projects-a-gloomy-year-for-fmcgcompanies-11588268892802.html

22. Invest in India. COVID-19: Impact on retail in India. Published Online. March 18, 2020.https://invest-india-revamp-static-files. s3.ap-south-1.amazonaws.com/s3fs-public/2020-03/RAI\%20 -\%20COVID\%20impact\%20on\%20Indian\%20Economy.PDF

23. The Hindu. The retail industry will take almost a year to recover from Covid-19 shock. Published Online. April 6, 2020. https:// www.thehindubusinessline.com/economy/retail-industry-willtake-almost-an-year-to-recover-from-covid-19-shock/article31271719.ece

24. Statista. Annual change in monthly retail trade revenue of consumer goods in China from March 2015 to March 2020. Available Online. Accessed on 23 May 2020. https://www.statista.com/ statistics/277912/china-change-in-trade-revenue-of-consumergoods-by-month/

25. Invest in India. COVID-19: Impact on retail in India. Published Online. March 18, 2020.https://invest-india-revamp-static-files. s3.ap-south-1.amazonaws.com/s3fs-public/2020-03/RAI\%20 -\%20COVID $\% 20$ impact $\% 20$ on\%20Indian $\% 20$ Economy.PDF

26. National Bureau of Statistics of China. (2020, March 17). Total Retail Sales of Consumer Goods Went down by 20.5 per cent in the first two months of 2020. Available Online. 17 March 2020. Accessed on 23 May 2020. http://www.stats.gov.cn/english/ PressRelease/202003/t20200317_1732694.html

27. Abrar P. $71 \%$ drop in FMCG demand due to Covid-19, zero orders in 95\% outlet: Study. Business Standard. Published Online. April 27, 2020. https://www.business-standard.com/article/ companies/71-drop-in-fmcg-demand-due-to-covid-19-zero-orders-in-95-outlets-study-120042701313 1.html

28. Bekkers E., Keck A., et al.; Methodology for the WTO Trade Forecast of April 8, 2020. WTO. Published Online. April 8, 2020. https://www.wto.org/english/news_e/pres20_e/methodpr855_e. pdf

29. ASSOCHAM. Recommendations for a National Response to the Economic Impact of Covid-19. Published Online. 2020. https:// www.assocham.org/upload/Recommendations-for-a-NationalResponse-to-the-Economic-Impact-of-Covid-19_Final.pdf

30. Deloitte. Impact of COVID-19 on consumer business in India. Published Online. March 30, 2020. https://www2.deloitte.com/ content/dam/Deloitte/in/Documents/consumer-business/inconsumer-impact-of-covid-19-on-consumer-business-in-indianoexp.pdf
31. Kantar. Lessons from China: FMCG's recovery after COVID-19. Published Online. 2020. https://www.kantar.com/Inspiration/Coronavirus/Lessons-from-China-FMCGs-recovery-afterCOVID-19

32. Ambwani VM. Covid-19: How the FMCG sector is pulling out all the stops to maintain the supply chain for essential products. THG Publishing. Published Online. 01 May 2020. https://www. thehindubusinessline.com/companies/covid-19-how-fmcg-sector-is-pulling-out-all-the-stops-to-maintain-supply-chain-foressential-products/article31482145.ece\#

33. PTI. ITC expects collaborations with unlikely partners to open new distribution channels. Published Online. 15 April 2020. https://economictimes.indiatimes.com/industry/cons-products/ fmcg/itc-expects-collaborations-with-unlikely-partners-toopen-new-supply-channels/articleshow/75158609.cms

34. PTI. Britannia Partners With Dunzo For Home Delivery Of Essentials Items. Published Online. 07 April 2020. https://www. bloombergquint.com/business/britannia-partners-with-dunzofor-home-delivery-of-essentials-food-items

35. Mukherjee W. Spencer's Retail partners Uber for last-mile delivery. The Economic Times. Published Online. 03 April 2020. https://economictimes.indiatimes.com/small-biz/startups/newsbuzz/spencers-retail-partners-uber-for-last-mile-delivery/articleshow/74961372.cms

36. Sheth H. Rapido ties up with Big Basket, Big Bazaar and Spencer's Retail for last-mile delivery amid lockdown. The Hindu. Published Online. April 7, 2020. https://www.thehindubusinessline.com/companies/rapido-ties-up-with-big-basket-big-bazaar-and-spencers-retail-for-last-mile-delivery-amid-lockdown/ article31279456.ece

37. Pathak K. Retail industry may take a year to recover. Mint. Published Online. April 6, 2020. https://www.livemint.com/industry/retail/retail-industry-may-take-9-12-months-to-overcomecovid-19-impact-rai-11586183105126.html

38. Abrar P. $71 \%$ drop in FMCG demand due to Covid-19, zero orders in 95\% outlet: Study. Business Standard. Published Online. April 27, 2020. https://www.business-standard.com/article/ companies/71-drop-in-fmcg-demand-due-to-covid-19-zero-orders-in-95-outlets-study-120042701313_1.html

39. Tanwar S. India's offline and online players are pooling their resources to survive the Covid-19 havoc. Quartz India. Published Online. 08 April 2020. https://qz.com/india/1833698/uber-bigbazaar-zomato-swiggy-come-together-amid-coronavirus/

40. Shashidhar A. Coronavirus impact: How Metro Cash and Carry is helping meet demand in red zones. Business Today. Published Online. 04 May 2020. https://www.businesstoday.in/current/corporate/coronavirus-impact-how-metro-cash--carry-is-helpingmeet-demand-in-red-zones/story/402857.html 